\title{
Peningkatan prestasi belajar PJOK pada siswa kelas 4 SDN 01 Sengare menggunakan media $e$-modul di masa pandemi
}

\author{
Aslori Lukman \\ SDN 01 Sengare Kabupaten Pekalongan
}

\begin{tabular}{ll}
\hline Article Info & ABSTRACT \\
\hline Article history: & $\begin{array}{l}\text { The aim of the researcher is to apply e-module media to improve PJOK } \\
\text { learning achievement in 4th grade students of SDN 01 Sengare. This research } \\
\text { was conducted on 4th grade students of SDN 01 Sengare, Pekalongan }\end{array}$ \\
$\begin{array}{l}\text { Received : 21 Juli 2021 } \\
\text { Revised : 6 September 2021 } \\
\text { Accepted : 25 September 2021 with an odd semester of the 2020/2021 academic year, totaling 22 } \\
\text { students. This type of research is classroom action research (CAR). As a } \\
\text { form of CAR, this research was carried out in several cycles. The results of } \\
\text { the study focused on the students' ability to solve problems. The flow in } \\
\text { classroom action research begins with planning action (planning), } \\
\text { implementing action (action), observing and evaluating the process and } \\
\text { results of the action, and reflecting, and so on until the improvement or } \\
\text { improvement is expected (success criteria). The result of this research is an } \\
\text { increase in the average of students in cycle 1 and cycle 2 respectively 79.50 } \\
\text { and 88.25. Then for classical completeness in cycle 1 and cycle 2, } \\
\text { respectively 77.27\% and 86.36\%. Because it has met the predetermined } \\
\text { success indicators, there is no need to proceed to the next cycle. } \\
\text { education; e-module }\end{array}$ & $\begin{array}{l}\text { aslorilukman3@gmail.com } \\
\text { (*) Corresponding Author: }\end{array}$ \\
\hline
\end{tabular}

How to Cite: Lukmam, A. (2021). Peningkatan prestasi belajar PJOK pada siswa kelas 4 SDN 01 Sengare menggunakan media e-modul di masa pandemi. Action Research Journal, 1(1): 25-29.

\section{PENDAHULUAN}

Subekti (2018) menyatakan pendidikan jasmani merupakan kegiatan yang melibatkan aktivitas fisik guna memperoleh kemampuan dan keterampilan jasmani. Hanief dan Sugito (2015) Pendidikan jasmani merupakan bagian yang tidak dapat dipisahkan dari kehidupan seseorang untuk dapat belajar lebih banyak hal yang berhubungan dengan afektif, kongnitif, dan psikomotor yang merupakan bekal untuk mencapai tujuan hidup. Mengingat begitu pentingnya pendidikan jasmani, maka dirancang secara sistematis ke dalam kurikulum dalam mata pelajaran Pendidikan Jasmani, Olahraga dan Kesehatan (PJOK) untuk pertumbuhan dan pengembanan, meningkatkan kemampuan dan keterampilan jasmani, kecerdasan dan pembentukan watak, serta nilai positif untuk mencapai tujuan pendidikan. PJOK sudah mulai diajarkan pada siswa kelas $1 \mathrm{SD}$.

Namun, dengan adanya pandemi Covid-19, telah mempengaruhi hampir seluruh aspek kehidupan manusia. Untuk memutus mata rantai penularan virus tersebut, banyak pembatasan yang dilakukan oleh pemerintah. Pendidikan anak sekolah dasar adalah salah satu sektor yang sangat terdampak kondisi pandemi ini. Sampai saat ini, kemendikbud masih belum mengijinkan pemerintah daerah di selain zona kuning dan hijau untuk membuka sekolah. Dalam rangka pemenuhan hak peserta didik untuk mendapatkan layanan pendidikan selama darurat penyebaran Corona Virus Disease (COVID-19), proses pembelajaran dilaksanakan melalui penyelenggaraan Belajar dari Rumah (BDR) sebagaimana tercantum dalam Surat Edaran Kemendikbud Nomor 3 Tahun 2020 tentang Pelaksanaan Kebijakan Pendidikan dalam Masa Darurat Penyebaran Corona Virus Disease (COVID-19) yang diperkuat dengan SE Sekjen Nomor 15 tahun 2020 tentang Pedoman Pelaksanaan BDR selama darurat Covid 19. 
Berdasarkan hal tersebut, mata pelajaran PJOK juga mendapatkan tantangan tersendiri. Kondisi kegiatan pembelajaran tiba-tiba berubah drastis dan mengharuskan pelaksanaan pembelajaran di rumah. Dengan pola pembelajaran di rumah tentunya tetap harus dapat meningkatkan tujuan pembelajaran PJOK yaitu meningkatkan kebugaran dan keterampilan motorik siswa, kemampuan yang mencakup aspek kognitif, afektif dan psikomotorik. Untuk itulah dibutuhkan sebuah media pembelajaran yang dapat menunjang tuntutan tersebut. Pemanfaatan tekhnologi informasi dan komunikasi dalam pembelajaran yang dikenal dengan istilah e-learning dapat menjadi solusi dari permasalahan diatas. E-learning merupakan salah satu pendekatan pembelajaran dengan menggunakan jasa bantuan perangkat elektronik.

Salah satu upaya yang dapat dilakukan guru dalam memfasilitasi pembelajaran bagi siswa adalah dengan menggunakan e-learning adalah penggunaan media e-modul. Gunadarma (2011) menyatakan e-modul sebagai sebuah bentuk penyajian media pembelajaran mandiri yang disusun dengan sistematis untuk mencapai tujuan pembelajaran tertentu. E-modul disajikan dalam format elektronik dimana proses pembelajaran di dalamnya dihubungkan dengan link link sebagai navigasi yang membuat siswa menjadi interaktif dengan program, dilengkapi dengan penyajian video tutorial, animasi dan audio untuk memperkaya pengalaman belajar. Arsal dkk (2019) menyatakan e-modul merupakan inovasi terbaru dari modul cetak, sehingga modul elektronik ini dapat diakses dengan bantuan smartphone.

Fausih dan T.D. (2015) menyatakan $e$-modul memiliki sifat hanya mencakup satu materi pembelajaran saja sehingga siswa benar fokus pada materi yang sedang diajarkan, keseluruhan komponen materi tertera di modul, modul dapat digunakan sendiri jadi tidak bergantung dengan media lain, sesuai dengan karakter siswa dan cocok dengan siswa. Hafsah dkk (2016) menyatakan dalam e-modul terdapat animasi yang mendekati keadaan nyatanya sehingga memudahkan siswa untuk memahami pembelajaran. E-modul merupakan media pembelajaran berbasis elektronik yang mengakomodasi siswa yang lamban menerima pelajaran, karena dapat memberikan iklim yang lebih bersifat afektif dengan cara yang lebih individual, tidak pernah lupa, tidak pernah bosan, sangat sabar dalam menjalankan instruksi seperti yang diinginkan program yang digunakan (Arsyad, 2013). Berdasarkan uraian di atas, maka peneliti ingin menerapkan media $e$-modul untuk meningkatkan prestasi belajar PJOK pada siswa kelas 4 SDN 01 Sengare.

\section{METODE PENELITIAN}

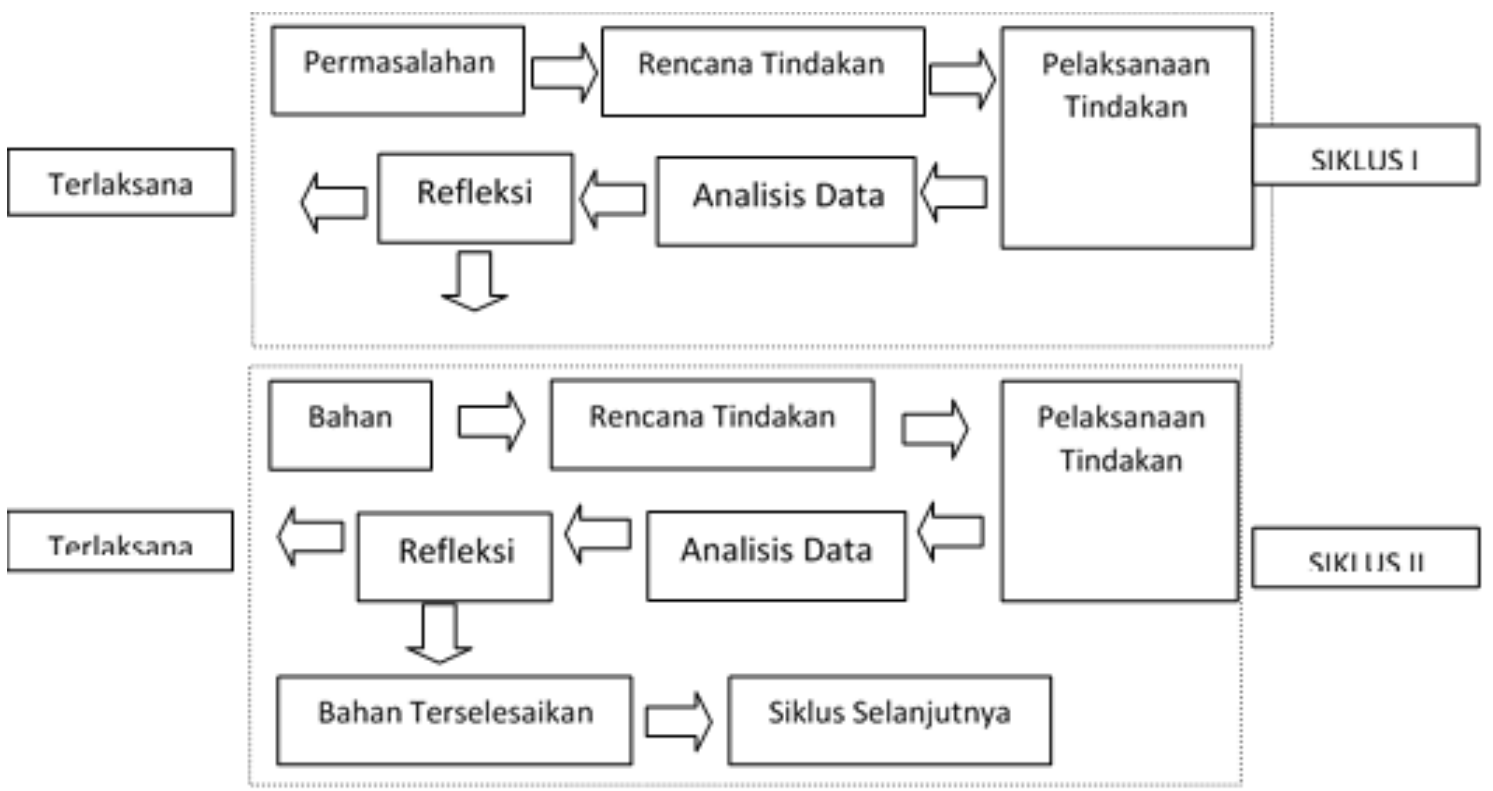

Gambar 1. Desain Penelitian Tindakan Kelas 
Penelitian ini dilaksanakan pada siswa kelas 4 SDN 01 Sengare Kabupaten Pekalongan dengan semester ganjil tahun ajaran 2020/ 2021 yang berjumlah 22 siswa. Jenis penelitian ini adalah penelitian tindaka kelas (PTK). Sebagai suatu bentuk PTK, penelitian ini dilaksanakan dalam beberapa siklus. Hasil penelitian dititik beratkan pada kemampuan siswa dalam menyelesaikan soal. Alur dalam penelitian tindakan kelas diawali dengan perencanaan tindakan (planning), penerapan tindakan (action), mengobservasi dan mengevaluasi proses dan hasil tindakan, dan melakukan refleksi, dan seterusnya sampai perbaikan atau peningkatan yang diharapkan (kriteria keberhasilan). Desain PTK dapat dilihat pada Gambar 1. Langkah-langkah kegiatan pada Gambar 1 dapat dijelaskan ke dalam siklus yang terdiri dari empat tahap, yaitu:

1. Perencanaan

Pada tahap ini, guru menyiapkan materi ajar yang akan diberikan kepada siswa, menyiapkan RPP, lembar observasi untuk siswa dan guru. Observasi direncanakan akan dilaksanakan setiap pertemuan serta menyiapkan media $e$-modul yang akan dipakai.

2. Tindakan

Pada tahap ini, guru melaksanakan apa yang telah dipersiapkan sebelumnya. Proses pembelajaran menggunakan media $e$-modul baik ketika penjelasan, diskusi, pemberian LKS maupun post test.

3. Pengamatan

Selama kegiatan pembelajaran, observer mengamati dan mencatat hasil dalam lembar observasi yang digunakan sebagai dasar refleksi setiap siklus dan dipadukan dengan hasil evaluasi.

4. Refleksi

Hasil yang diperoleh dari pengamatan dan hasil evaluasi pada tindakan siklus 1 digunakan sebagai dasar apakah sudah memenuhi target atau perlu dilakukan penyempurnaan pada pengorganisasian pembelajaran agar siklus 2 diperoleh hasil yang lebih baik, begitu seterusnya.

Pengumpulan data pada penelitian ini meliputi observasi, tes, dokumentasi dan wawancara. Sedangkan teknik analisis data dilihat dari jumlah siswa yang mengalami peningkatan prestasi belajar, yang diperoleh dari siklus 1 dan siklus berikutnya.

1. Nilai rata-rata

Nilai rata-rata peserta didik dihitung dengan menggunakan rumus:

$X=\frac{\sum X}{N}$

Keterangan

$X \quad=$ nilai rata-rata

$\sum X=$ jumlah nilai siswa

$N \quad=$ jumlah siswa

2. Ketuntasan klasikal

Ketuntasan klasikal merupakan nilai dari prestasi belajar tiap siklus secara keseluruhan setelah proses pembelajaran menggunakan media $e$-modul.

Persentase $=\frac{\text { Jumlah siswa yang mencapai KKM }}{\text { Jumlah seluruh siswa }} \times 100 \%$

Indikator keberhasilan pada penelitian ini adalah untuk ketuntasan belajar individu jika proporsi jawaban benar peserta didik lebih dari KKM yang telah ditetapkan dan untuk ketuntasan belajar klasikal jika minimal $85 \%$ dari seluruh peserta didik telah mencapai KKM.

\section{HASIL DAN PEMBAHASAN}

Nilai posttest mata pelajaran PJOK pada siswa kelas 4 SDN 01 Sengare semester gasal tahun ajaran 2020/2021 diperoleh dari proses siklus 1 dan siklus 2. Evaluasi pada setiap siklus dilakukan menggunakan instrumen soal sebanyak 15 soal. Soal tersebut diberikan setelah proses 
pembelajaran menggunakan media e-modul. Siklus 1 dilaksanakan pada 7 September 2020 s.d. 18 September 2020, untuk siklus 2 dilaksanakan pada 21 September 2020 s.d. 2 Oktober 2020. Tabel 1 menyatakan data hasil penelitian pada masing-masing siklus sebagai berikut.

Tabel 1. Peningkatan prestasi belajar siswa kelas 4 SDN 01 Sengare untuk masing-masing siklus

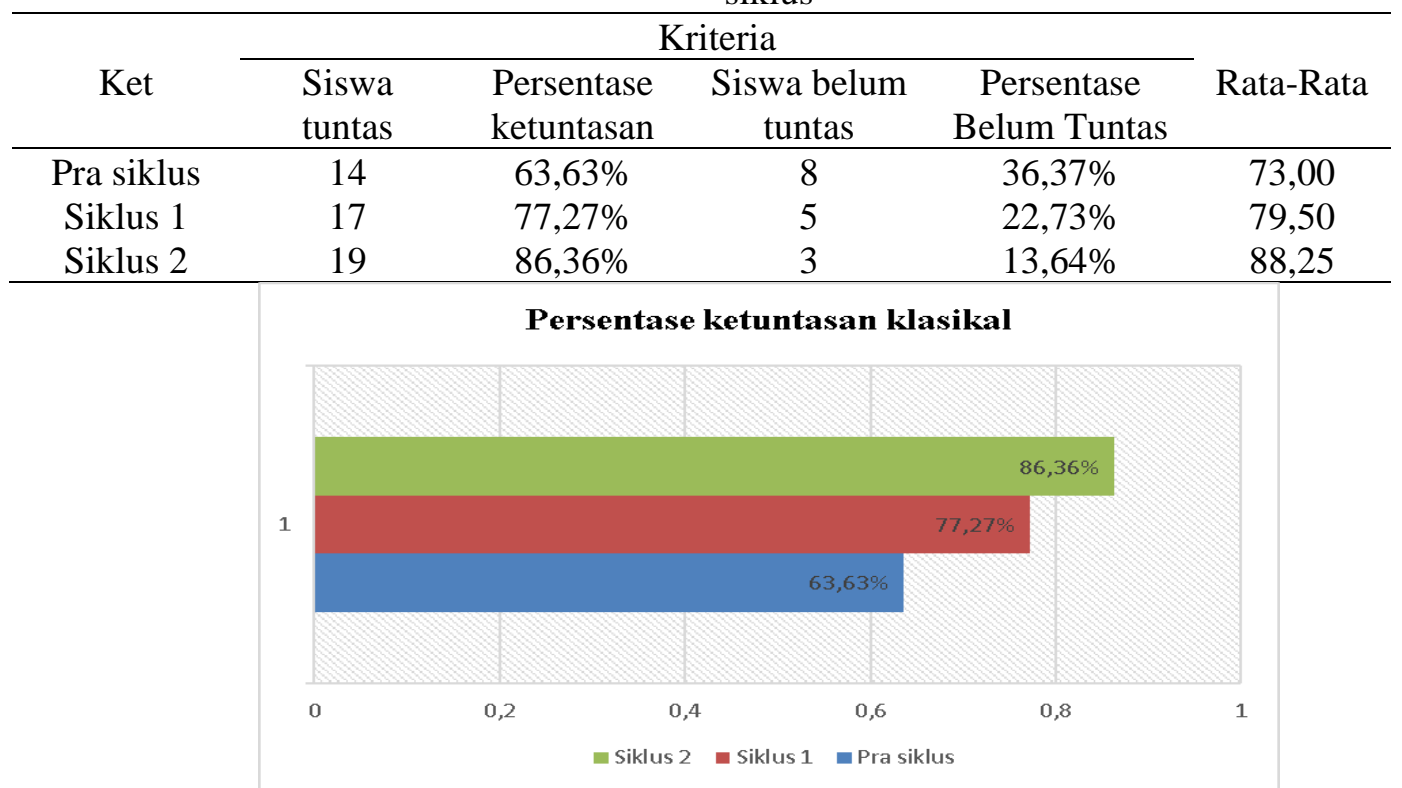

Gambar 2. Peningkatan rata-rata ketuntasan belajar klasikal mata pelajaran PJOK Siswa kelas 4 SDN 01 Sengare

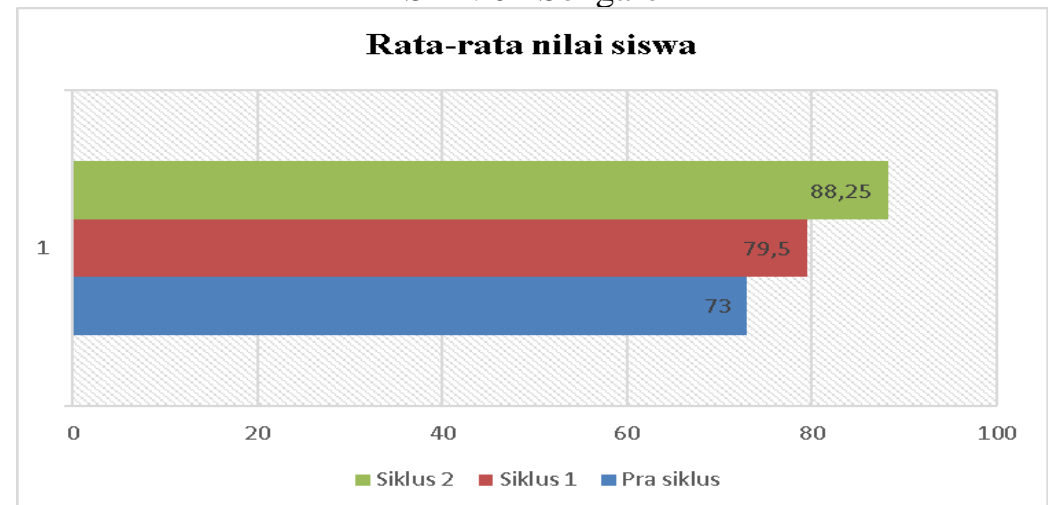

Gambar 3. Peningkatan rata-rata prestasi belajar mata pelajan PJOK siswa kelas 4 SDN 01 Sengale

Berdasarkan visualisasi di atas, terjadi peningkatan baik ketuntasan klasikal dan juga rata-rata nilai prestasi belajar siswa. Pada pra siklus, rata-rata nilai siswa sebesar 73, kemudian untuk siklus 1 dan 2 masing-masing 79,5 dan 88,25. Hal tersebut sangat beralasan mengingat ketika guru memfasilitasi siswa menggunakan media $e$-modul, siswa lebih antusias dalam proses pembelajaran. Untuk ketuntasan klasikal, pada siklus 1 belum memenuhi indikator keberhasilan yang telah ditetapkan yaitu $85 \%$. Pada siklus 2 sudah memenuhi indikator keberhasilan yang telah ditetapkan sehingga tidak perlu dilanjutkan untuk siklus 3. Persentase ketuntasan klasikal pada siklus 1 sebesar 77,27\% dengan siswa sebanyak 17 orang. Sementara pada siklus 2 sebesar $86,36 \%$ dengan siswa sebanyak 19 orang.

Peningkatan ketuntasan klasikal tersebut mengindikasikan bahwa penggunaan media $e$ modul sangat efektif dalam pembelajaran di rumah. Sebagimana pernyataan Gunadarma (2011) menyatakan e-modul sebagai sebuah bentuk penyajian media pembelajaran mandiri yang disusun dengan sistematis untuk mencapai tujuan pembelajaran tertentu. Arsal dkk (2019) 
menyatakan e-modul merupakan inovasi terbaru dari modul cetak, sehingga modul elektronik ini dapat diakses dengan bantuan smartphone. Penggunaan media e-comic dapat meningkatkan ansuiasme, lebih aktif siswa karena didalamnya terdapat animasi gambar yang menarik.Hafsah dkk (2016) menyatakan dalam e-modul terdapat animasi yang mendekati keadaan nyatanya sehingga memudahkan siswa untuk memahami pembelajaran. E-modul juga lebih bersifat menarik, tidak pernah lupa, tidak pernah bosan, sangat sabar dalam menjalankan instruksi seperti yang diinginkan program yang digunakan (Arsyad, 2013).

\section{SIMPULAN}

Berdasarkan hasil penelitian di atas, dapat disimpulkan bahwa penggunaan google classroom dapat meningkatkan prestasi belajar pada siswa kelas 4 SDN 01 Sengare Kabupaten Pekalongan. Hal tersebut didukung oleh data dari masing-masing siklus yang terjadi peningkatan baik rata-rata kelas maupun persentase ketuntasan klasikal yang telah memenuhi indikator keberhasilan yang ditetapkan. Saran yang dapat diberikan oleh peneliti adalah pentingnya kreativitas dari guru untuk memanfaatkan berbagai teknologi yang dibutuhkan dalam proses pembelajaran di masa pandemi agar tujuan pembelajaran dapat berjalan secara efektif dan maksimal. Dibutuhkan pula dukungan dari semua pihak agar pelaksanaan pembelajaran di rumah dapat berjalan dengan lancar.

\section{DAFTAR PUSTAKA}

Arsal, Muhammad, dkk. 2019. Pengembangan Media Pembelajaran E-Modul Materi Sistem Peredaran Darah Pada Kelas XI MIPA SMAN 6 Barru. Prosiding Seminar Nasional Biologi VI Harmonisasi Pembelajaran Biologi pada Era Revolusi 4.0. UNM Malang.

Arsyad, A. 2013. Media pembelajaran. Jakarta: PT. Raja Grafindo Persada.

Deviyanti, dkk. 2020. Pengembangan Media E-Learning Berbasis Google Classroom Untuk Meningkatkan Hasil Belajar Siswa Pada Mata Pelajaran Ekonomi Kelas XI Di SMA Unggul Sakti Jambi. Jurnal Manajemen Pendidikan dan Ilmu Sosial, Vol. 1, No. 1: 303-316.

Fausih, M., \& T, D. 2015. Media Modul Elektronik di Sekolah Menengah Kejuruan. Jurnal UNESA. Vol. No. 01. Hal. 1-9.

Gunadharma. 2011. Pengembangan Modul Elektronik sebagai Sumber Belajar Untuk Mata Kuliah Multimedia Design. Jurusan Teknologi Pendidikan, Fakultas Ilmu Pendidikan, Universitas Negeri Jakarta: Skripsi (tidak diterbitkan)

Hanief, Y. N., \& Sugito, S. 2015. Membentuk Gerak Dasar Pada Siswa Sekolah Dasar Melalui Permainan Tradisional. Jurnal SPORTIF: Jurnal Penelitian Pembelajaran, Vol. 1, No.1. Hal. 100-113

Subekti, Tri Bagus Agiasta, Yulingga Nanda Hanief. Hendra Mashuri. 2018. Meningkatkan Hasil Belajar Passing Bawah Bolavoli melalui Permainan 3 on 3 pada Siswa Sekolah Dasar Jurnal Pendidikan Jasmani dan Olahraga. Vol. 3 No. 2. Hal. 161 - 166

Sutia, C. dkk. 2019. Student's Response to Project Learning with Online Guidance Through Google Classroom on Biology Projects. Journal of Physics: Conference Series, vol. 1157: 1-5.

Surat Edaran Nomor 3. 2020. Pencegahan Corono Virus Disease (COVID-19) Pada Satuan Pendidikan. Jakarta. Kementrian Pendidikan dan Kebudayaan. 